\title{
Atividade alelopática de extratos aquosos de Aristolochia esperanzae O. Kuntze na germinação e no crescimento de Lactuca sativa L. e Raphanus sativus L.
}

\author{
Ana Beatriz Gatti ${ }^{1,3}$, Sonia Cristina Juliano Gualtieri de Andrade Perez ${ }^{2,3}$ e Maria Inês Salgueiro Lima ${ }^{2,3}$
}

\author{
Recebido em 23/06/2003. Aceito em 19/11/2003
}

\begin{abstract}
RESUMO - (Atividade alelopática de extratos aquosos de Aristolochia esperanzae O. Kuntze na germinação e no crescimento de Lactuca sativa L. e Raphanus sativus L.). O objetivo deste trabalho foi analisar os efeitos de extratos aquosos de diferentes órgãos de Aristolochia esperanzae na germinação e no crescimento de alface e rabanete. Todos os extratos preparados obedeceram à proporção de $100 \mathrm{~g}$ de material vegetal fresco para $300 \mathrm{~mL}$ de água destilada, que produziu o extrato considerado $100 \%$ concentrado. A partir deste, foram feitas diluições com água destilada para 75, 50 e $25 \%$. Nos testes de germinação foram avaliados os efeitos dos extratos obtidos de folha, caule, raiz, fruto e flor a 100, 75, 50 e $25 \%$. Para o teste de crescimento foram utilizados extratos de folha, caule e raiz na concentração de 100 e $50 \%$. Nos testes de germinação foram utilizadas quatro repetições de 30 sementes distribuídas em placas de Petri forradas com duas folhas de papel de filtro umedecidas com $5 \mathrm{~mL}$ dos referidos extratos, secas durante $12 \mathrm{~h}$ e reumedecidas com $4,5 \mathrm{~mL}$ de água destilada. No primeiro teste avaliou-se a percentagem e a velocidade de germinação das sementes. No teste de crescimento, as sementes foram previamente germinadas (2-4mm de radícula) e depois transferidas para caixas plásticas contendo os substratos de papel de filtro e fibra de coco umedecidos com os respectivos extratos. Avaliou-se a altura da parte aérea, o comprimento radicular, a massa seca das plântulas e a presença de anormalidades nas plântulas. Os testes foram mantidos à temperatura constante de $27^{\circ} \mathrm{C}$. Através dos resultados obtidos pode-se concluir que os extratos de folha foram os que mais afetaram a percentagem de germinação e que todos os extratos e as diferentes concentrações retardaram a germinação de sementes de alface e de rabanete. Quanto ao teste de crescimento, podese verificar que os extratos de caule e de raiz causaram anormalidades nas plântulas. As plântulas crescidas no substrato papel de filtro apresentaram maior inibição do crescimento, em relação àquelas crescidas no substrato fibra de coco. A concentração dos extratos foi a principal responsável pelo estímulo ou inibição causada no crescimento das plântulas de alface e rabanete.
\end{abstract}

Palvras-chave: alelopatia, Aristolochia, alface, rabanete

\begin{abstract}
Allelopathic activity of aqueous extracts of Aristolochia esperanzae O. Kuntze in the germination and growth of Lactuca sativa L. and Raphanus sativus L.). This work analyzed the effects of aqueous extracts of Aristolochia esperanzae organs in the germination and initial growth of lettuce and radish. All the extracts were prepared using $100 \mathrm{~g}$ of plant fresh material $+300 \mathrm{~mL}$ of distilled water to produce the extract $100 \%$ concentrated. This extract was diluted with distilled water to produce a final concentrations of 75,50 and $25 \%$. The germination was evaluated by tests using the extracts of leaf, stem, root, fruit and flower, with concentration of 100,75 , 50 , and $25 \%$. In the seedlings growth, the extracts of leaf, stem, and root were used in the concentration of 100 and $50 \%$. In the germination tests, four replicates of 30 seeds were distributed in Petri dishes with two filter paper moistened with $5 \mathrm{~mL}$ of the extracts, dried during 12 hours and moistened again with $4,5 \mathrm{~mL}$ of distilled water. In the first test, the rate and germination percentage were evaluated. In the growth test, the seeds were previously germinated (2-4mm radicle length) and transferred for plastic boxes containing the filter paper or coconut fiber, moistened with the extracts. The shoot height, radicle length, dry mass and the presence of abnormalities in the seedlings were evaluated. Both tests were maintained at constant temperature $\left(27^{\circ} \mathrm{C}\right)$. The results showed that the leaf extracts affected strongly the germination percentage and all the extract, in different concentrations, delayed the germination of lettuce and radish seeds. In the growth tests could be verified that the stem and root extracts caused abnormality in the seedlings. The seedlings grown in filter paper presented bigger growth inhibition in relation to seedlings from coconut fiber. The extract concentration was the main responsible for the promotion or inhibition caused on lettuce and radish seedlings growth.
\end{abstract}

Key words: allelophaty, Aristolochia, lettuce, radish

\section{Introdução}

Rice (1984) definiu o termo alelopatia como o efeito prejudicial e/ou benéfico entre plantas através de interações químicas, incluindo os microrganismos.

Os compostos químicos que possuem atividade alelopática são produtos do metabolismo secundário produzido pelas plantas, chamados de aleloquímicos,

\footnotetext{
1 Programa de Pós-Graduação em Ecologia e Recursos Naturais, Universidade Federal de São Carlos, Via Washington Luiz, Km 235, C. Postal 676, CEP 13565-905, São Carlos, SP, Brasil

2 Departamento de Botânica - UFSCar

3 Autores para correspondência: abgatti@yahoo.com.br; dsp@ power.ufscar.br; ines@ power.ufscar.br
} 
substâncias alelopáticas, fitotoxinas ou apenas produtos ou metabólitos secundários. Estas substâncias estão presentes em todos os tecidos das plantas, incluindo folhas, flores, frutos, raízes, rizomas, caules e sementes (Putnan \& Tang 1986). Para Friedman (1995), todos os órgãos da planta têm potencial para armazenar aleloquímicos, mas a quantidade e o caminho pelos quais são emitidos difere de espécie para espécie.

Harbone $(1991 ; 1997)$ sugeriu que os metabólitos secundários tenham função defensiva, ajudando no crescimento da planta que o produz. Estes compostos possuem função ecológica de defender a planta contra herbívoros e atuam como atrativos para polinizadores, feromônio, além da ação alelopática. Fischer (1991) demonstrou que muitas vezes, a ação alelopática deriva dos monoterpenos, sesquiterpenos e diterpenos.

A ação dos vários aleloquímicos está envolvida na inibição e em modificações nos padrões de crescimento ou desenvolvimento das plantas. Os aleloquímicos podem ser seletivos em suas ações e as plantas podem ser seletivas em suas respostas, por este motivo tornase difícil sintetizar o modo de ação destes compostos (Seigler 1996). No entanto, vários autores listaram inúmeros mecanismos de ação dos aleloquímicos, que afetam vários processos fisiológicos das plantas (Rice 1984; Einhelling 1986; Putnan \& Tang 1986; Inderjit \& Dakshini 1995; Chou 1999; Reigosa et al. 1999).

A produção de aleloquímicos pelas plantas pode ser regulada por diversos fatores ambientais, como a temperatura, a intensidade luminosa, a disponibilidade de água e nutrientes, textura do solo e microrganismos presentes (Chou 1986). A influência de outros fatores, como a da radiação UV, doenças e ataque de insetos, modificam diretamente a taxa de produção dos aleloquímicos (Einhelling 1996). Além disso, os fatores relacionados ao estresse podem aumentar a atividade biológica referente aos aleloquímicos. Kong et al. (2002) verificaram que o efeito alelopático de Ageratum conyzoides sobre várias espécies foi aumentado, quando a planta foi colocada em condições de déficit nutricional e competição.

Segundo Einhelling (1996), a inibição tipicamente alelopática resulta da ação combinada de grupos de aleloquímicos que, coletivamente, interferem em vários processos fisiológicos.

Diante da variedade da atuação dos compostos secundários, principalmente na ação alelopática, Bagchi et al. (1997) consideram os aleloquímicos como um recurso para o desenvolvimento de herbicidas naturais ou de um estimulante para o crescimento de algumas plantas. A maioria dos trabalhos relata que os efeitos dos compostos alelopáticos se relacionam aos processos fisiológicos da planta receptora e de maneira geral, agem como inibidores da germinação e do crescimento (Juan Jiménez-Osornio et al. 1996; Viles \& Reese 1996; Rawat et al. 1998; Vaccarini et al. 1999). Porém, alguns trabalhos demonstraram que estes compostos podem atuar como promotores de crescimento (Yamada et al. 1995; Yokotani-Tomita et al. 1998). Aparentemente, a maior parte, senão todos os compostos orgânicos que são inibitórios em alguma concentração, são estimulantes quando presentes em menores concentrações (Rice 1984).

Segundo Chou (1986; 1999), a alelopatia tem sido reconhecida como importante mecanismo ecológico, que influencia a dominância e sucessão das plantas, formação de comunidades, vegetação clímax, manejo e produtividade de culturas. Esta interação alelopática, responsável pelo estabelecimento e sobrevivência de certas espécies no ambiente, é feita por um mecanismo de defesa das plantas, que vem sendo adquirido ao longo de um processo de evolução (Nishimura \& Mizutani 1995).

Muitos estudos estão sendo realizados na tentativa de diminuir o uso de herbicidas comerciais através da alelopatia com o manejo e o controle das ervas daninhas, por meio da rotação de culturas, sistemas adequados de semeadura entre espécies e entresafras, além de sistemas agroecológicos. (Durigan \& Almeida 1993; Baruah et al. 1994; Weston 1996; Chou et al. 1998; Wu et al. 2000; Khan et al. 2002; Kato-Noguchi 2003).

Rizvi et al. (1999) enfatizaram a importância dos sistemas agroflorestais (uso de associações de espécies arbóreas com a agricultura) para o uso sustentável da terra e o aumento da produtividade agrícola. Nestas associações, o conhecimento das potencialidades alelopáticas destas espécies é de essencial importância para o sucesso dos sistemas agroflorestais. Os mesmos autores listaram aproximadamente 80 espécies consideradas agroflorestais com potencialidades alelopáticas sobre diversas outras espécies.

Para constatar a ação alelopática os bioensaios têm grande importância, pois através deles consegue-se controlar alguns parâmetros (temperatura, disponibilidade de água, etc.) para investigar os mecanismos que estão interagindo. Astarita et al. (1996) enfatizaram que o potencial osmótico dos extratos podem exercer efeito negativo adicionado aos efeitos da atividade alelopática, atrasando, reduzindo ou mesmo impedindo a germinação das sementes e também afetando o estabelecimento das plântulas. Os 
mesmos autores e também Miró et al. (1998), Souza Filho et al. (1999) e Mazzafera (2003) realizaram testes biológicos, paralelamente aos ensaios de alelopatia, com soluções de potenciais osmóticos conhecidos com o intuito de discriminar a interferência do potencial osmótico dos extratos na inibição puramente alelopática, e indicaram a utilização de polietilenoglicol para a preparação destas soluções. Segundo Inderjit \& Dakshini (1995), os resultados obtidos em laboratórios devem ser inseridos em contexto mais geral para que não se crie uma distância entre os ensaios laboratoriais e o ambiente natural.

Alguns trabalhos evidenciam a presença de terpenos, diterpenos, lignina, ácido aristolóquio, entre outras substâncias em espécies de Aristolochia, incluindo A. esperanzae. (Priestap et al. 1971; Lopes et al. 1987; 1988; Lopes \& Bolzani 1988).

Aristolochia esperanzae O. Kuntze, espécie pertencente à família Aristolochiaceae, planta herbácea, rastejante ou trepadeira, com folhas alternadas membranosas orbiculares-reniformes, glabras, estípulas amplas, flor zigomorfa com perianto formando um grande papo encimado por tubo bilabiado, totalmente pintalgada em tons castanho-avermelhados mesclados com outras cores mais claras. No interior do tubo encontram-se numerosos pêlos. A flor exala odor de carne podre que atrai insetos, possui frutos capsulares septicida 6-valvares. Conhecida popularmente por papo-de-peru, cachimbo-de turco, mil-homens e jarrinha (Ferri 1969). Aristolochia esperanzae é espécie pioneira e considerada a mais freqüente nos cerrados do Estado de São Paulo (Capellari Jr. 1992).

Neste contexto, resolveu-se investigar os efeitos de diferentes concentrações de extratos de folha, caule, e raiz, fruto e flor de Aristolochia esperanzae na germinação e no crescimento de alface (Lactuca sativa L.) e de rabanete (Raphanus sativus L.). Além disso, avaliou-se a possibilidade de utilização do papel de filtro e da fibra de coco como substratos para avaliação do crescimento de plântulas, sob a ação dos extratos aquosos.

\section{Material e métodos}

Para a avaliação do potencial alelopático de Aristolochia esperanzae foi coletado material vegetal de populações desta espécie presentes em áreas pertencentes ao câmpus da Universidade Federal de São Carlos.

O material vegetal foi coletado em maio/2002 e mantido congelado até a realização dos experimentos.
Os extratos aquosos da planta foram feitos utilizando-se folha, caule, raiz, fruto e flor para os bioensaios de germinação. Em virtude dos resultados obtidos nos testes de germinação e da disponibilidade de material, optou-se em utilizar apenas extratos de folha, caule e raiz para os testes de crescimento.

Para a obtenção dos extratos, os materiais vegetais frescos foram primeiramente pesados, picados e em seguida, triturados com o auxílio de um liqüidificador industrial durante cinco minutos, e deixados descansar durante 30 minutos. Decorrido este período, o extrato foi filtrado em filtro de pano e em seguida utilizou-se uma bomba elétrica a vácuo acoplada a um funil de Buckner com papel de filtro quantitativo para segunda filtragem. O material filtrado foi recolhido em frasco Kitazato e imediatamente utilizado.

Todos os extratos foram feitos obedecendo à proporção de $100 \mathrm{~g}$ de material vegetal para $300 \mathrm{~mL}$ de água destilada, sendo este considerado o extrato bruto ( $100 \%$ de concentração). A partir deste, foram feitas diluições com água destilada para 75,50 e $25 \%$. O efeito destas quatro concentrações foi comparado com o da água destilada, considerada como controle ( $0 \%)$.

Nos bioensaios de germinação e de crescimento foram utilizadas sementes de alface (Lactuca sativa L., cultivar Grand rapids) e de rabanete (Raphanus sativus L., cultivar Crimson gigante).

Bioensaio de Germinação - para este experimento foram utilizados extratos de folha, caule, raiz, fruto e flor nas quatro concentrações acima citadas, mais o grupo controle. Foram colocados $5 \mathrm{~mL}$ dos extratos sobre duas folhas de papel de filtro que forravam as placas de Petri de $9 \mathrm{~cm}$ diâm. Em seguida, as placas contendo os papéis de filtro umedecidos com extrato, foram secas em capela com exaustor durante $12 \mathrm{~h}$. Decorrido este período, o papel de filtro foi reumedecido com $4,5 \mathrm{~mL}$ de água destilada. Os experimentos foram conduzidos com quatro repetições de 30 sementes de alface ou rabanete por placa de Petri, mantidos em câmara climatizada (Estufa BOD) a $24^{\circ} \mathrm{C}$, na ausência de luz. As sementes apenas receberam luz durante as contagens que foram realizadas em intervalos de $12 \mathrm{~h}$ durante os sete primeiros dias, e em intervalos de $24 \mathrm{~h}$ até totalizar 10 dias após a semeadura. Foram consideradas germinadas as sementes que apresentaram $2 \mathrm{~mm}$ de protusão radicular (Brasil 1992). A percentagem (G) e a velocidade $(\mathrm{V})$ de germinação foram calculadas segundo as fórmulas citadas em Labouriau \& Valadares (1976). 
O delineamento experimental foi inteiramente casualizado, com quatro repetições para cada tratamento. Os valores de percentagem foram transformados em arco seno ( $\sqrt{\%})$ (Labouriau 1983). A comparação das médias foi feita através do teste de Tukey a $5 \%$ de probabilidade.

Bioensaio de crescimento - neste experimento foi utilizado extrato de folha, caule e raiz de Aristolochia esperanzae nas concentrações de $100 \%$ (100g de material vegetal para $300 \mathrm{~mL}$ de água destilada) e a partir desta concentração fez-se as diluições com água destilada para $50 \%$, que foram comparadas com o controle (água destilada).

Os experimentos foram realizados em caixas plásticas transparentes $(11 \times 29 \times 9,5 \mathrm{~cm})$ contendo dois tipos de substratos: papel de filtro e fibra de coco (substrato feito a partir de fibras do mesocarpo do fruto de Cocus nucifera). Cada caixa continha quatro repetições de 10 sementes. Os extratos foram colocados em contato com o substrato $12 \mathrm{~h}$ antes da montagem do experimento para haver melhor absorção. No substrato papel de filtro foram utilizadas duas folhas umedecidas com $38 \mathrm{~mL}$ de extrato e no substrato de fibra de coco foram colocadas $140 \mathrm{~g}$ de fibra por caixa, umedecida com $650 \mathrm{~mL}$. As sementes (alface e rabanete) foram previamente germinadas a $24^{\circ} \mathrm{C}$, em placas de Petri, forradas com duas folhas de papel de filtro umedecidas com $4,5 \mathrm{~mL}$ de água. Após decorridas $45 \mathrm{~h}$, as sementes germinadas (apresentando entre 2 a $4 \mathrm{~mm}$ de radícula) foram transplantadas para as caixas plásticas contendo os substratos umedecidos com água (controle) e os extratos de folha, caule e raiz a 50 e $100 \%$. As caixas foram cobertas com sacos plásticos transparentes e mantidas em câmara climatizada (Estufa BOD) a $24^{\circ} \mathrm{C}$, com fotoperíodo de $12 \mathrm{~h}$.

As avaliações foram realizadas no $7^{\circ}$ dia após a semeadura, com medições da altura da planta $(\mathrm{mm})$, considerada a distância do colo da planta até o ápice e o comprimento da raiz $(\mathrm{mm})$, considerada a distância do colo da planta até o ápice meristemático do sistema radicular. Tanto a medida da parte aérea da planta quanto o comprimento radicular são parâmetros biométricos descritos por Benincasa (1988). As plântulas foram classificadas em normais ou anormais, de acordo com as especificações de Brasil (1992).

Depois de feitas as medidas biométricas, as plântulas de cada repetição foram separadas em normais e anormais e colocadas em sacos de papel, mantidos em estufa a $80^{\circ} \mathrm{C}$ durante $48 \mathrm{~h}$ até a estabilização do peso. Decorrido este período, o material vegetal foi mantido em dessecador para ser pesado em balança analítica de precisão (AND, modelo HR-200), obtendo-se assim os valores de massa seca total das plântulas (mg).

$\mathrm{O}$ delineamento experimental foi inteiramente casualizado, com quatro repetições para cada tratamento. Os dados obtidos foram submetidos à análise de variância (ANOVA), e o resultado, quando comparadas todas as causas de variação, (substrato, anormalidade das plântulas, diferentes órgãos e concentrações) foi de interação significativa para todos os parâmetros estudados. Assim, as médias foram comparadas duas a duas, com o uso do teste de Duncan a $5 \%$ de probabilidade.

Características físico-químicas - o pH de cada extrato utilizado nos bioensaios foi medido com o auxílio de um pHmetro (Analion, modelo PM608); esta medida foi feita com os extratos em sua maior concentração. A medição da concentração molar também foi realizada com os extratos em sua maior concentração, utilizandose um osmômetro ( $\mu$ Osmotte, modelo 5004 automatic osmometer), onde foram utilizados $50 \mu 1$ de cada extrato mantido a temperatura de $24^{\circ} \mathrm{C}$; essa medida foi expressa em $\mu \mathrm{Osmol} / \mathrm{Kg}$ e transformada em MPa.

Para determinar a influência do potencial osmótico dos extratos, foi realizado um bioensaio de germinação com sementes de alface e rabanete em soluções de polietilinoglicol (PEG-6000) com os seguintes valores de potenciais osmóticos: $0,-0.2,-0.3,-0.4 \mathrm{MPa}$ segundo especificações de Villela (1991). Este experimento foi realizado utilizando-se a mesma metodologia descrita para os bioensaios de germinação.

Rendimento dos extratos de A. esperanzae - antes da adição de cada extrato nas placas de Petri, as folhas de papel de filtro foram pesadas (Peso I), e após esta adição $(5 \mathrm{~mL}$ dos extratos nas placas e evaporados durante $12 \mathrm{~h}$ ), os papéis de filtro foram novamente pesados (Peso II) em balança analítica $(\mathrm{mg})$. A diferença entre as pesagens (Peso I - Peso II) dividido pelo volume utilizado demonstra o rendimento de cada extrato $(\mathrm{mg} / \mathrm{mL})$, ou seja, quanto de material vegetal proveniente de cada extrato foi necessário para inibir a germinação de 30 sementes de alface ou rabanete. O rendimento total de cada extrato foi calculado através da média aritmética de quatro repetições.

\section{Resultados e discussão}

Bioensaio de germinação - quando foram comparadas as causas de variação (órgãos e concentração) 
registrou-se a presença de interação significativa para os parâmetros estudados (percentagem e velocidade de germinação). Os resultados, referentes à influência alelopática de A. esperanzae na germinação de alface e rabanete estão resumidos nas Fig. 1 e Fig. 2.

Na Figura 1 pode-se observar que os extratos de fruto e de flor não influenciaram significativamente o processo germinativo das sementes de alface, em nenhuma das concentrações testadas. No entanto, os extratos de caule e raiz influenciaram a viabilidade das sementes, tanto menor quanto mais concentrado o extrato. Os valores de percentagem de germinação são diferentes estatisticamente do controle a partir da concentração de $100 \%$ para o extrato de caule e $75 \%$ para o de raiz. O extrato de folha foi o que provocou a maior inibição na germinação de sementes de alface, onde, a partir da concentração de $50 \%$, foi observada redução significativa dos valores, em relação ao controle. Esta diferença torna-se mais acentuada na concentração de $75 \%$, e a inibição completa da germinação ocorreu com o extrato $100 \%$ concentrado. Estes resultados assemelham-se aos de Saxena et al. (1996), que observaram que o aumento da concentração dos extratos de Pennisetum glaucum diminuiu as taxas de germinação de sementes da própria espécie.

Quanto à velocidade de germinação das sementes de alface, pode-se notar que os extratos causaram atraso no processo germinativo a partir da concentração de $25 \%$. Observa-se então, que mesmo
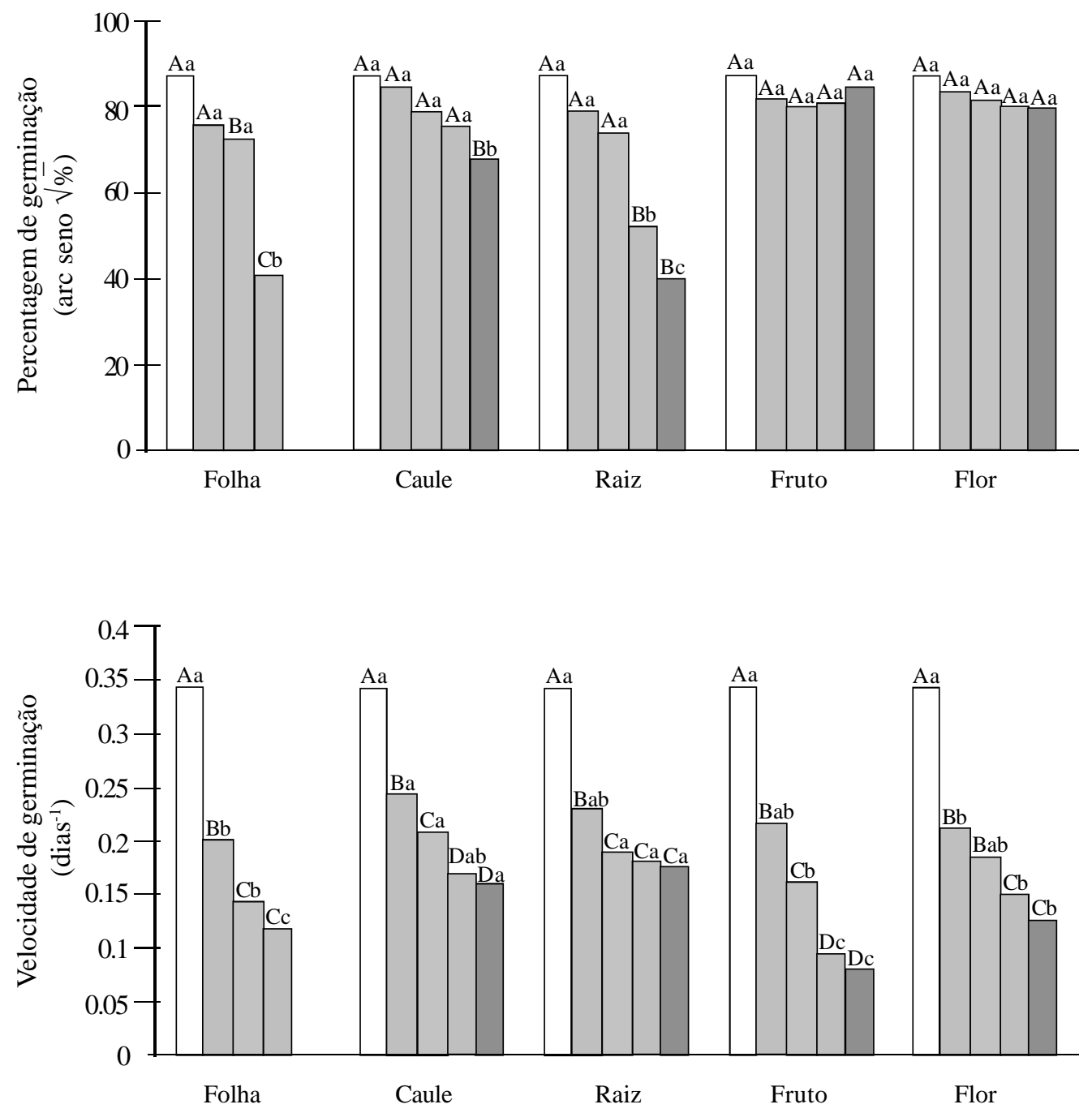

Figura 1. Valores médios de percentagem e velocidade de germinação de sementes de alface (Lactuca sativa L.) submetidas à ação de diferentes extratos de Aristolochia esperanzae O. Kuntze em quatro concentrações, mais o controle ( $0 \%)$. Médias seguidas pelas mesmas letras maiúsculas para as concentrações $(0,25,50,75,100 \%)$ e minúsculas para os órgãos (folha, caule, raiz, flor e fruto) não diferem entre si, pelo teste de Tukey a $5 \%$ de probabilidade. $\square=0 \%$, 目 $=25 \%$, 田 $=50 \%$, $\square=75 \%$, 团 $=100 \%$. 
os extratos de fruto e flor, que não alteraram a percentagem de germinação das sementes, atrasaram a germinação das mesmas. Percebe-se que há tendência de decréscimo nos valores de velocidade de germinação quando se aumenta a concentração dos extratos, e este fato é bem evidenciado quando se usou extrato concentrado de folha e de fruto, onde foram registrados os menores valores de velocidade (Fig. 1).

Pinã-Rodrigues \& Lopes (2001) também observaram que os extratos de Mimosa caesalpinaefolia não afetaram a percentagem de germinação, porém, os mesmos extratos reduziram a velocidade de germinação de sementes de ipê-amarelo (Tabebuia alba).

A Figura 2 apresenta os valores de percentagem e velocidade de germinação das sementes de rabanete mantidas em meio contendo os extratos de A. esperanzae. O extrato de flor causou inibição da germinação apenas na concentração de $100 \%$, e o extrato de folha proporcionou efeito inibitório na taxa de geminação de sementes de rabanete a partir de $75 \%$ de concentração. Os extratos de caule, raiz e fruto não influenciaram significativamente a percentagem de germinação das sementes de rabanete.
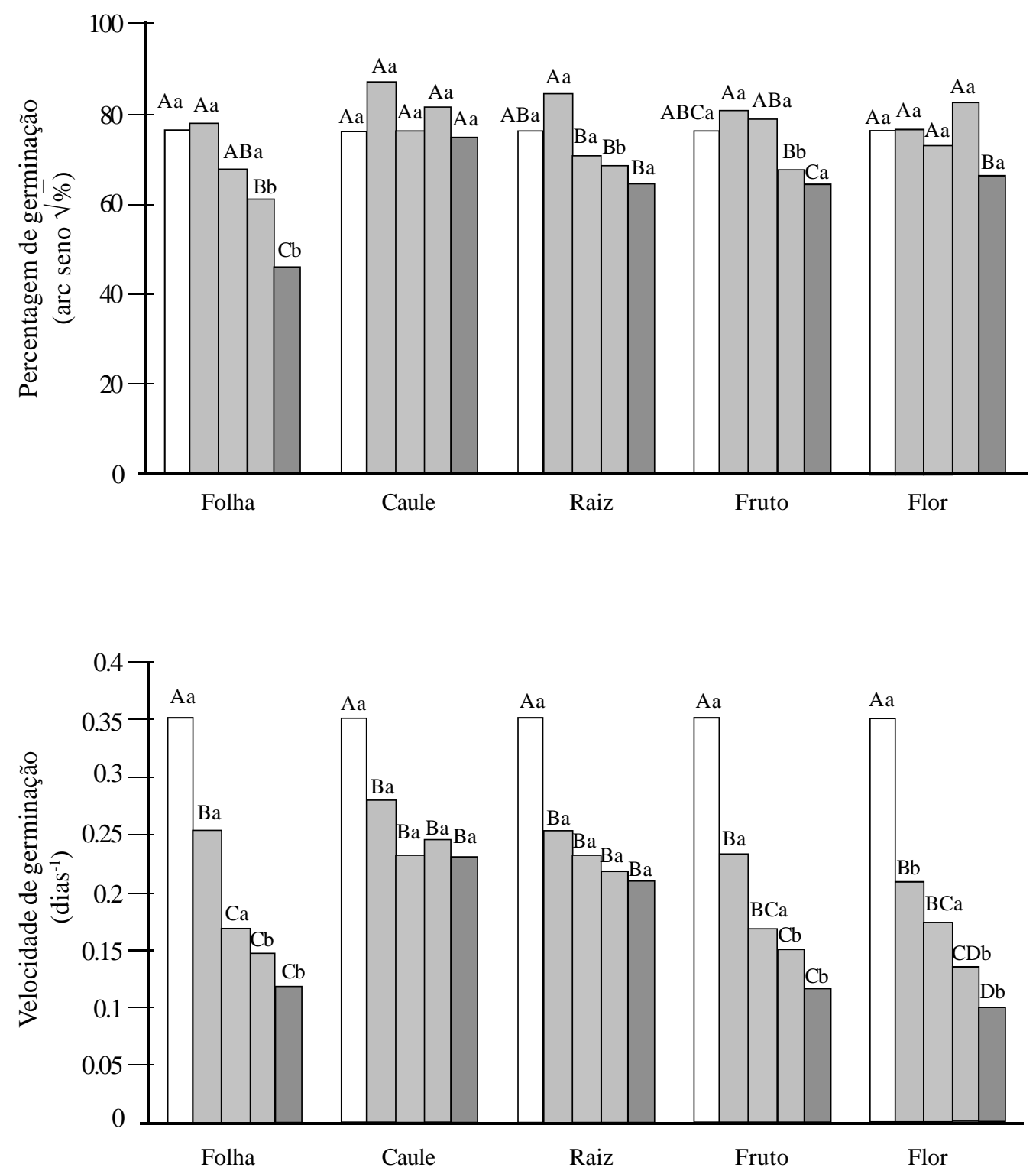

Figura 2. Valores médios de percentagem e velocidade de germinação de sementes de rabanete (Raphanus sativus L.) submetidas à ação de diferentes extratos de Aristolochia esperanzae O. Kuntze em quatro concentrações, mais o controle (0\%). Médias seguidas pelas mesmas letras maiúsculas para as concentrações $(0,25,50,75,100 \%)$ e minúsculas para os órgãos (folha, caule, raiz, flor e fruto) não diferem entre si, pelo teste de Tukey a $5 \%$ de probabilidade. $\square=0 \%$, 目 $=25 \%$, 田 $=50 \%, \square=75 \%$, 团 $=100 \%$. 
Quanto à velocidade de germinação das sementes de rabanete verificou-se que todos os extratos diminuíram significativamente estes valores, quando comparados com os obtidos para o controle, e estes decréscimos acentuam-se com o aumento da concentração dos extratos. Os menores valores de velocidade foram registrados com a utilização dos extratos mais concentrados de flor, fruto e folha (Fig. 2).

Diante dos resultados obtidos para a germinação das sementes de alface e rabanete, na presença dos extratos de A. esperanzae, percebe-se que os extratos de folha foram os que proporcionaram maior redução na percentagem de germinação. No entanto, todos os outros extratos, provenientes dos diferentes órgãos de A. esperanzae, diminuíram a velocidade de germinação das sementes, em todas as concentrações, quando comparados com o grupo controle (Fig. $1 \mathrm{e}$ Fig. 2).

Diferenças nas respostas alelopáticas de compostos de diferentes órgãos de uma mesma planta também foram registradas com Chenopodium ambrosioides (Juan Jimenez-Osornio et al. 1996), Artemisia absinthium (Delachiave et al. 1999) e Triticum aestivum (Wu et al. 2000). Friedmam (1995) afirmou que a quantidade de aleloquímicos e sua liberação pelos órgãos da planta são variações que ocorrem de espécie para espécie.

Bioensaio de crescimento - quando foram comparadas todas as causas de variação (substrato, diferentes órgãos e concentrações) obteve-se interação significativa para todos os parâmetros estudados (altura das plântulas, comprimento da raiz e massa seca total).

Em relação à influência alelopática no crescimento de plântulas de alface e rabanete foi registrada anormalidade principalmente no sistema radicular, onde as raízes primárias se apresentaram atrofiadas, defeituosas (Fig. 3d e Fig. 4c, 4d), e em alguns casos, praticamente ausentes (Fig. 3c, 3e). Algumas plântulas também apresentaram raízes curtas e desproporcionais em relação às outras estruturas da planta (Fig. $3 \mathrm{~g}$ e Fig. 4f).

A Tab. 1 contém a percentagem de plântulas consideradas anormais, crescidas em papel de filtro e em fibra de coco. Pode-se observar que os extratos de caule e raiz nas concentrações de 50 e $100 \%$, quando adicionados ao papel de filtro, provocaram anormalidade em quase todas as plântulas de alface que nele cresceram. Nota-se ainda que neste substrato o extrato de raiz na concentração de $100 \%$ provocou a morte de todas as plântulas de alface (estas apresentavam-se completamente apodrecidas,
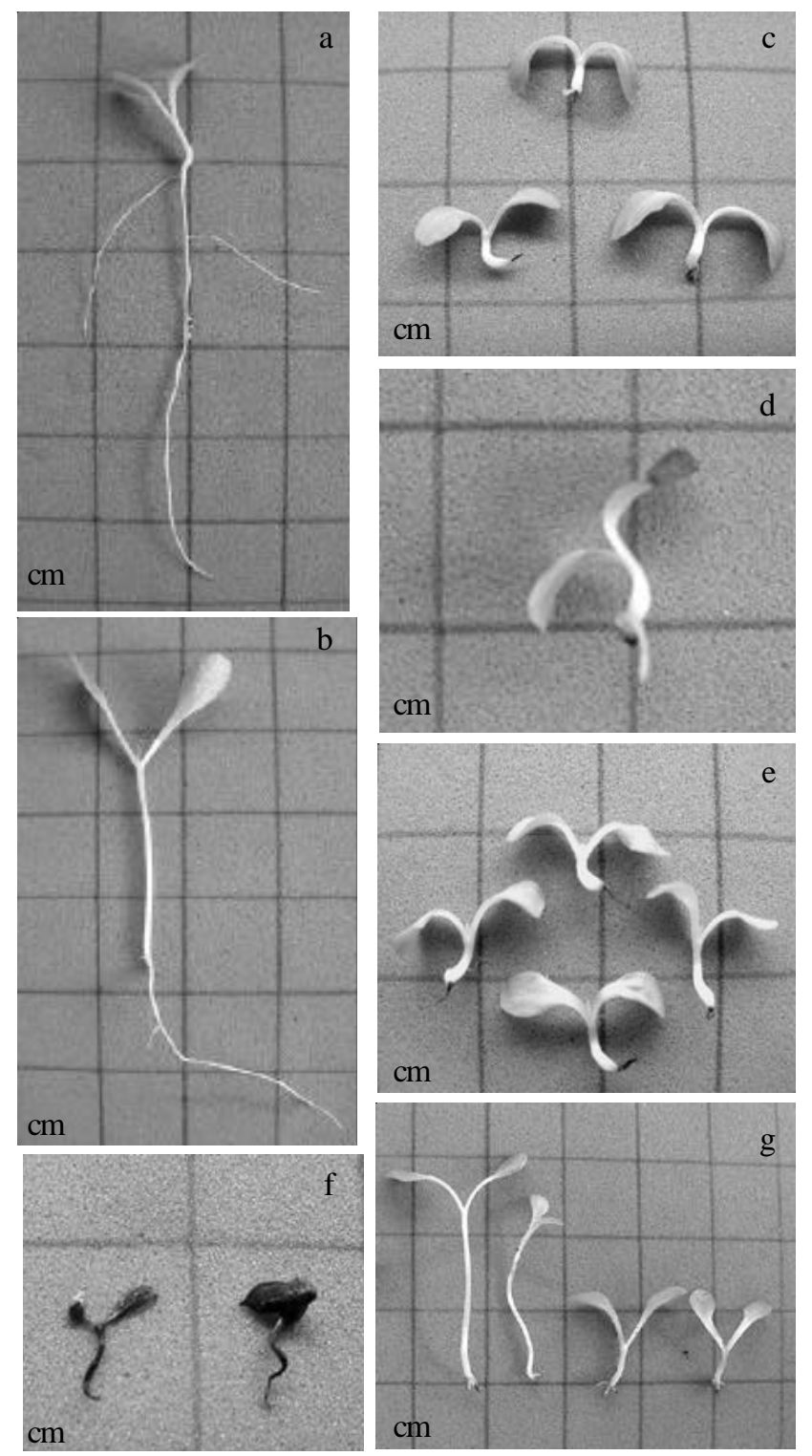

Figura 3. Anormalidade de plântulas de alface (Lactuca sativa L.) quando crescidas em papel de filtro ou fibra de coco, umedecidos com diferentes extratos (caule e raiz) e concentrações (50 e 100\%) de Aristolochia esperanzae O. Kuntze. O extrato de folha não provocou anormalidade nas plântulas. a. Controle papel de filtro. b. Controle fibra de coco. c. Caule - $50 \%$ papel de filtro. d. Caule - $100 \%$ papel de filtro. e. Raiz - 50\% papel de filtro. f. Raiz $100 \%$ papel de filtro. g. Raiz - $100 \%$ fibra de coco.

impossibilitando a medição) (Fig. 3f e Tab. 1). A anormalidade das plântulas de alface também foi evidenciada quando se utilizou como substrato a fibra de coco, porém, apenas no extrato de raiz a $100 \%$ de concentração (Fig. 3g e Tab. 1).

Quanto ao percentual de anormalidade encontrado em rabanete (Tab. 1), observa-se que plântulas crescidas em papel de filtro umedecido com os extratos de caule e raiz, ambos a $100 \%$ de concentração, 

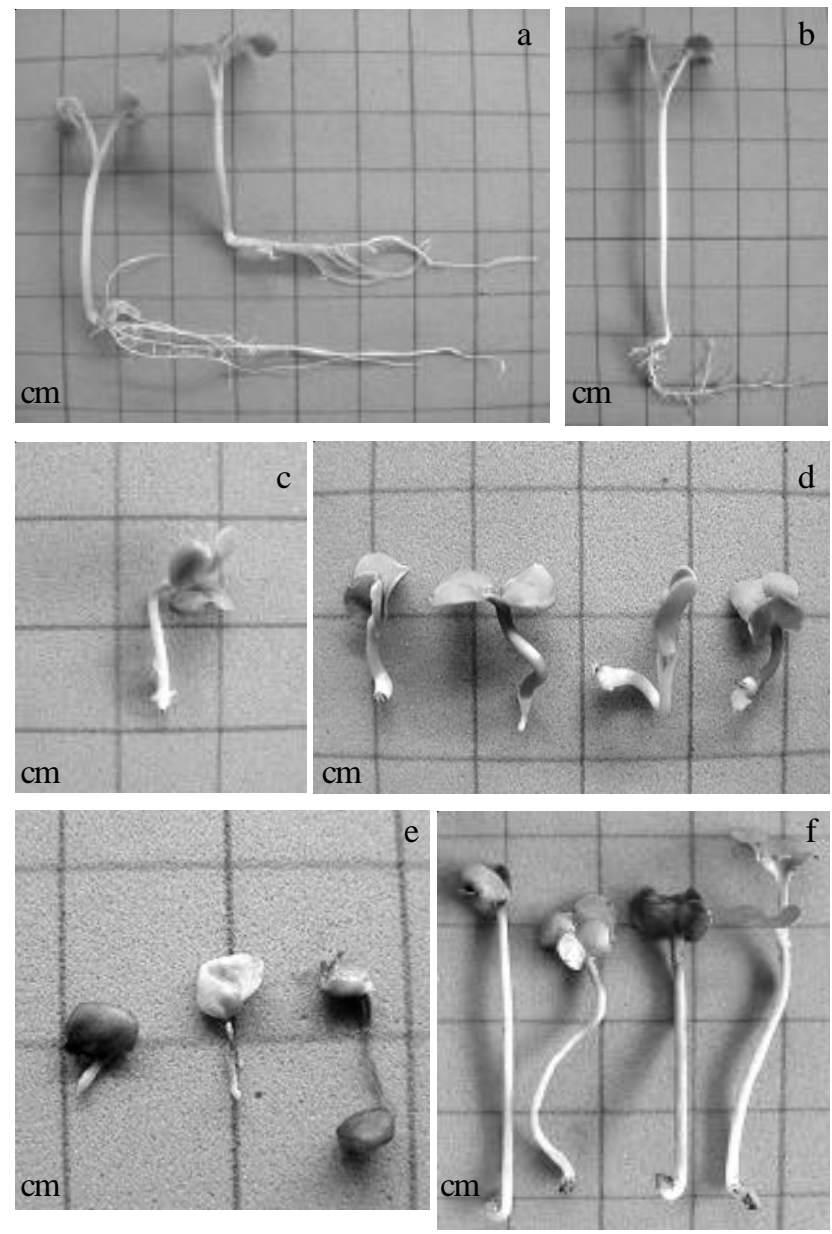

Figura 4. Anormalidade de plântulas de rabanete (Raphanus sativus L.) quando crescidas em papel de filtro ou fibra de coco, umedecidos com diferentes extratos (caule e raiz) e concentrações (50 e 100\%) de Aristolochia esperanzae O. Kuntze. O extrato de folha não provocou anormalidade nas plântulas. a. Controle papel de filtro. b. Controle fibra de coco. c. Caule - $100 \%$ papel de filtro. d. Raiz - 50\% papel de filtro. e. Raiz - $100 \%$ papel de filtro. f. Raiz - $100 \%$ fibra de coco.

causaram anormalidade em todas as plântulas. Além disto, provocaram a mortalidade de $22,5 \%$ e $32,5 \%$ das plântulas, respectivamente. $\mathrm{O}$ uso de extrato de raiz, na concentração de $50 \%$, causou anormalidade em mais de $80 \%$ das plântulas.

Para as plântulas de rabanete crescidas na fibra de coco, a percentagem de anormalidade foi menor do que no papel de filtro, onde os extratos de caule na concentração de $50 \%$ e $100 \%$ causaram anormalidade em apenas 5 e 17,5\% das plântulas, respectivamente (Tab. 1). O extrato de raiz na concentração de $100 \%$ causou anormalidades em 57,5\% das plântulas (Fig. $4 \mathrm{f}$ e Tab. 1).

Anormalidades em plântulas de alface também foram observadas por Medeiros \& Luchesi (1993) com
Tabela 1. Percentagem de plântulas anormais e mortas de alface (Lactuca sativa L.) e rabanete (Raphanus sativus L.) quando crescidas em papel de filtro e fibra de coco umedecidos com extratos de folha, raiz e caule de Aristolochia esperanzae O. Kuntze em duas concentrações (50 e 100\%). Percentagem média de quatro repetições de 10 plântulas por tratamento. Os extratos de folha não causaram anormalidade (Anor.) e mortalidade (Mort.).

\begin{tabular}{llcccc}
\hline & & \multicolumn{2}{c}{ Alface } & \multicolumn{2}{c}{ Rabanete } \\
\cline { 3 - 6 } Substratos & & $\begin{array}{c}\text { Papel de } \\
\text { filtro }\end{array}$ & $\begin{array}{c}\text { Fibra de } \\
\text { coco }\end{array}$ & $\begin{array}{c}\text { Papel de } \\
\text { filtro }\end{array}$ & $\begin{array}{c}\text { Fibra de } \\
\text { coco }\end{array}$ \\
\hline Extratos & & & & & \\
Caule - 50\% & (Anor.) & 100 & - & - & 5 \\
& (Mort.) & - & - & - & - \\
Caule - 100\% & (Anor.) & 100 & - & 100 & 17,5 \\
& (Mort.) & - & - & 22,5 & - \\
Raiz - 50\% & (Anor.) & 85 & - & 82,5 & - \\
& (Mort.) & - & - & - & - \\
Raiz - 100\% & (Anor.) & 100 & 87,5 & 100 & 57,5 \\
& (Mort.) & 100 & - & 32,5 & - \\
\hline
\end{tabular}

o uso de extratos aquosos de ervilhaca (Vicia sativa) e por Aquila (2000), com extratos de erva-mate (Ilex paraguariensis). A presença de anormalidade em raízes parece ser um bom parâmetro para registro de anormalidade de plântulas, pois este órgão é mais sensível à ação alelopática que a parte aérea (Pires \& Oliveira 2001). A avaliação da anormalidade das plântulas é instrumento valioso nos experimentos de alelopatia e a necrose da radícula é o sintoma mais comum da anormalidade (Ferreira \& Aquila 2000).

Ao analisar o crescimento das plântulas crescidas em papel de filtro e na fibra de coco, umedecidos em água (controle), verificou-se que as plântulas apresentaram desenvolvimento diferenciado. Observou-se que as plântulas de alface e rabanete crescidas em fibra de coco eram mais altas que aquelas crescidas em papel de filtro (Fig. 3, 4; Fig. 5, 8). No entanto, estes valores invertem-se quando se analisa o comprimento radicular, onde as plântulas crescidas em fibra de coco apresentaram valores significativamente menores do que as que cresceram em papel de filtro (Fig. 3, 4; Fig. 6, 9). Este fato pode ser explicado pela característica física dos substratos, onde no papel de filtro as raízes estão livres e na fibra de coco, têm que exercer pressão de crescimento para penetrarem no substrato.

A partir dos resultados da Fig. 5 pode-se verificar, que os valores de altura da parte aérea das plântulas de alface, em geral, foram maiores quando crescidas 
na fibra de coco, se comparados com aquelas crescidas em papel de filtro. Na fibra de coco, os valores de altura da parte aérea foram estatisticamente maiores utilizando extratos de folha nas concentrações de $50 \mathrm{e}$ $100 \%$ e de caule e raiz na concentração de $50 \%$, quando comparados ao grupo controle, evidenciando assim, um estímulo no crescimento destas plântulas.

Quando se utilizou papel de filtro umedecido com extrato de folha na concentração de $50 \%$, também foi observado aumento na altura da parte aérea, se

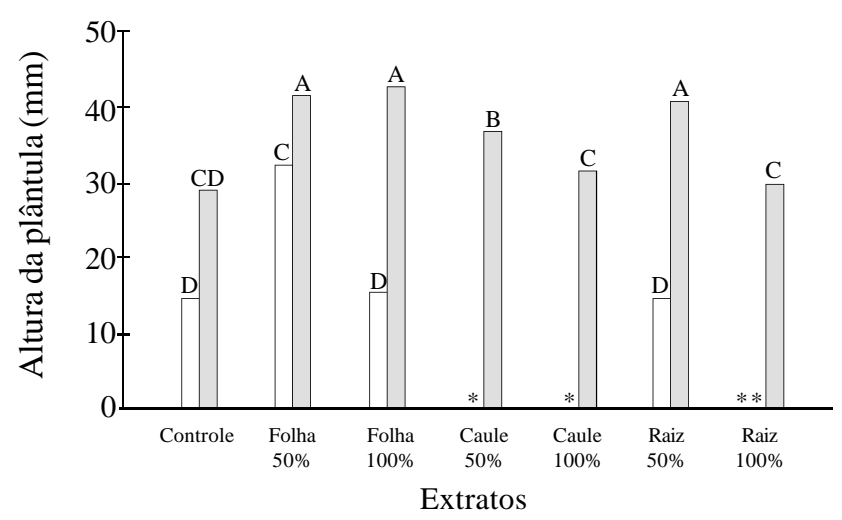

Figura 5. Valores médios de altura de parte aérea de plântulas normais de alface (Lactuca sativa $\mathrm{L}$.) crescidas em papel de filtro e fibra de coco, umedecidos com diferentes extratos (folha, caule e raiz) de Aristolochia esperanzae O. Kuntze, em duas concentrações (50 e $100 \%$, mais o controle - 0\%). Médias seguidas pelas mesmas letras não diferem entre si, pelo teste de Duncan a 5\% de probabilidade. $*=$ todas as plântulas anormais, $* *=$ todas as plântulas mortas; $\square=$ Papel filtro; $\square=$ Fibra de coco.

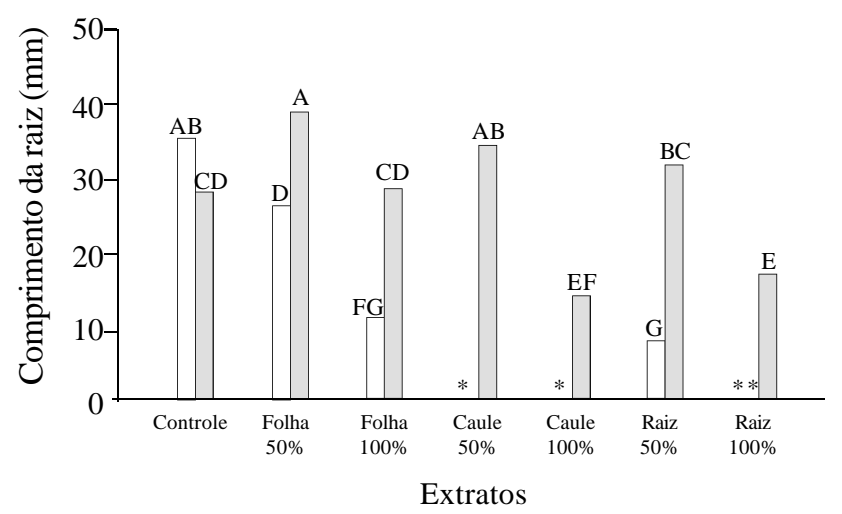

Figura 6. Valores médios de comprimento radicular de plântulas normais de alface (Lactuca sativa $\mathrm{L}$.) crescidas em papel de filtro e fibra de coco, umedecidos com diferentes extratos (folha, caule e raiz) de Aristolochia esperanzae O. Kuntze, em duas concentrações (50 e 100\%, mais o controle - 0\%). Médias seguidas pelas mesmas letras não diferem entre si, pelo teste de Duncan a $5 \%$ de probabilidade. $*=$ todas as plântulas anormais, $* *=$ todas as plântulas mortas; $\square=$ Papel filtro; $\square=$ Fibra de coco. comparado ao grupo controle. Oposto a este resultado, os extratos de folha na concentração de $100 \%$ e de raiz na concentração de $50 \%$ apresentaram valores que não diferiram estatisticamente do controle (Fig. 5).

Em relação ao comprimento da raiz das plântulas de alface, crescidas na fibra de coco umedecida com os extratos de folha, caule e raiz, na concentração de $50 \%$, estes apresentaram valores estatisticamente maiores que os do controle, evidenciando que estes

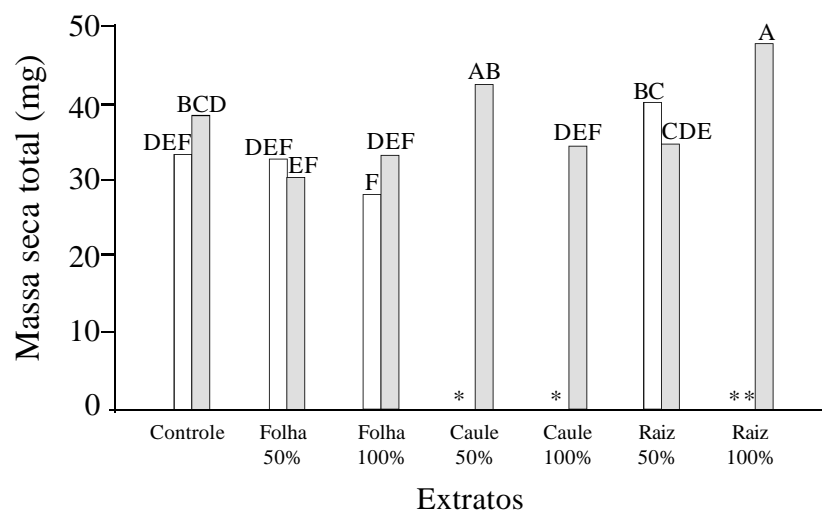

Figura 7. Valores médios de massa seca total de plântulas normais de alface (Lactuca sativa $\mathrm{L}$.) crescidas em papel de filtro e fibra de coco, umedecidos com diferentes extratos (folha, caule e raiz) de Aristolochia esperanzae O. Kuntze, em duas concentrações (50 e $100 \%$, mais o controle - 0\%). Médias seguidas pelas mesmas letras não diferem entre si, pelo teste de Duncan a 5\% de probabilidade. $*=$ todas as plântulas anormais, $* *=$ todas as plântulas mortas; $\square=$ Papel filtro; $\square=$ Fibra de coco.

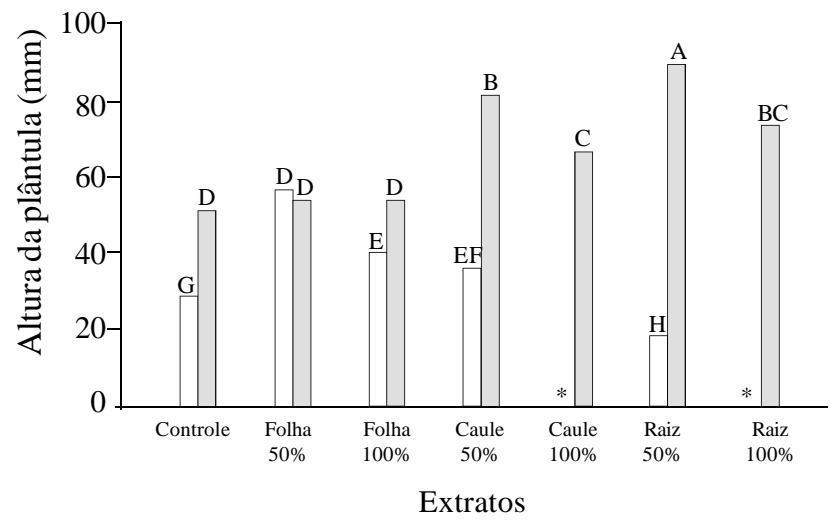

Figura 8. Valores médios de altura de parte aérea de plântulas normais de rabanete (Raphanus sativus $\mathrm{L}$.) crescidas em papel de filtro e fibra de coco, umedecidos com diferentes extratos (folha, caule e raiz) de Aristolochia esperanzae O. Kuntze, em duas concentrações (50 e 100\%, mais o controle - 0\%). Médias seguidas pelas mesmas letras não diferem entre si, pelo teste de Duncan a $5 \%$ de probabilidade. $*=$ todas as plântulas anormais; $\square=$ Papel filtro; $\nabla=$ Fibra de coco. 


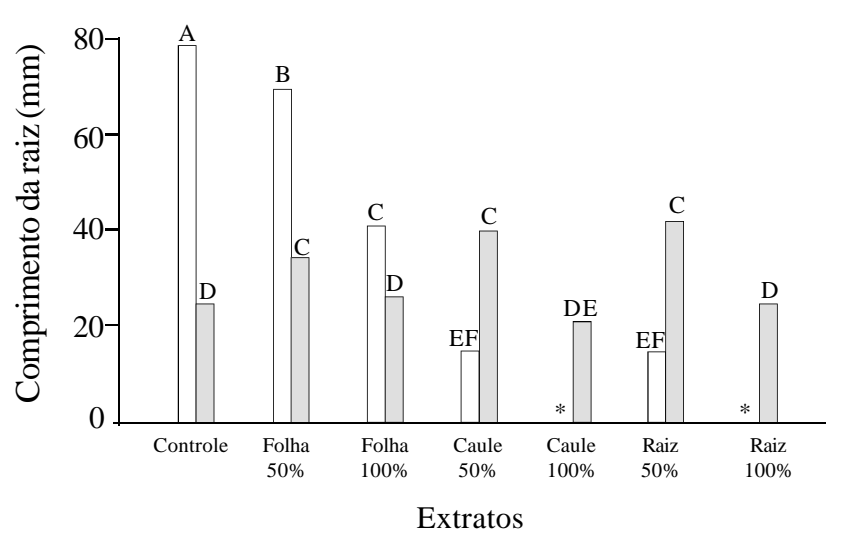

Figura 9. Valores médios de comprimento radicular de plântulas normais de rabanete (Raphanus sativus L.) crescidas em papel de filtro e fibra de coco, umedecidos com diferentes extratos (folha, caule e raiz) de Aristolochia esperanzae O. Kuntze, em duas concentrações (50 e 100\%, mais o controle - 0\%). Médias seguidas pelas mesmas letras não diferem entre si, pelo teste de Duncan a $5 \%$ de probabilidade. $*=$ todas as plântulas anormais; $\square=$ Papel filtro; $\square=$ Fibra de coco.

extratos, nesta concentração, estimularam o crescimento do sistema radicular. No entanto, estes extratos (caule e raiz) em concentração mais elevada (100\%), passaram a inibir o crescimento das raízes (Fig. 6). Jacobi \& Ferreira (1991) observaram que extratos mais concentrados de Mimosa bimucronata inibiram o crescimento da radícula de várias espécies cultivadas, como: Lactuca sativa, Oryza sativa, Daucus carota, Cichorium endivia, Brassica pekinensis, Cucumis sativus, Brassica oleracea, Lycopersicon esculentum.

As plântulas crescidas no papel de filtro apresentaram valores de comprimento radicular, em todos os extratos e concentrações, estatisticamente menores, em relação ao controle. Resultados semelhantes foram obtidos por Chou et al. (1998) em plântulas de alface com extratos de Acacia confusa.

Quanto à massa seca total observa-se que apenas alguns valores, como os observados para os extratos de caule e raiz, nas concentrações de 50 e $100 \%$ respectivamente, não diferiram significativamente do grupo controle, tanto nas plântulas crescidas na fibra de coco quanto nas crescidas no papel de filtro (Fig. 7).

Houve maior crescimento da parte aérea das plântulas de rabanete crescidas na fibra de coco sob a influência dos extratos de caule e raiz nas concentrações de 50 e $100 \%$ se comparados com o controle (Fig. 8). As plântulas de rabanete crescidas no papel de filtro umedecidos com extratos de folha a 50 e $100 \%$ de concentração e caule $(50 \%)$ apresentaram incremento no crescimento, quando comparadas com o grupo controle. No entanto, o extrato de raiz a 50\% inibiu o crescimento da parte aérea destas plântulas se comparadas com o controle (Fig. 8).

Quando se analisou o comprimento da raiz principal das plântulas de rabanete crescidas na fibra de coco, o uso de todos os extratos na menor concentração (50\%) estimulou o crescimento; em comparação ao grupo controle, e os valores das plântulas crescidas com os demais extratos não diferiram do controle. (Fig. 9). Vaccarini \& Bonetta (2000) verificaram que tanto o aleloquímico, quanto a sua concentração, proporcionaram respostas diferentes em raízes de plântulas de alface.

As plântulas de rabanete crescidas em papel de filtro umedecido com todos os extratos apresentaram valores de comprimento radicular menores que os do controle. Nota-se grande diferença na resposta proporcionada pelos extratos de folha, se comparada com as de caule e raiz, nos quais houve acréscimos na percentagem de anormalidade.

Quanto à massa seca total, para plântulas de rabanete crescidas na fibra de coco não há tendência de diminuição ou de aumento dos valores, quando se comparam os diferentes extratos e suas concentrações (Fig. 10). No entanto, os extratos e suas concentrações interferiram no crescimento das plântulas, e este fato pode ser explicado devido a um investimento diferenciado de matéria orgânica, ou na raiz ou na parte aérea, dependendo do extrato ou da concentração utilizados.

Segundo Rodrigues et al. (1992), os compostos alelopáticos são inibidores de germinação e crescimento, pois interferem na divisão celular, permeabilidade de membranas e na ativação de enzimas.

Diante dos resultados obtidos no bioensaio de crescimento destacam-se diferenças entre as respostas provenientes dos dois substratos testados. Observa-se que a percentagem de plântulas anormais foi superior quando se utilizou o papel de filtro. Em geral, os valores da altura da parte aérea foram maiores nas plântulas crescidas na fibra de coco. Além disso, notou-se que a inibição por compostos aleloquímicos foi maior quando se utilizou o papel de filtro como substrato.

Pires et al. (2001) aplicaram extrato de leucena (Leucaena leucocephala) em plantas daninhas e verificaram que o efeito fitotóxico foi menor em solo quando comparado com o papel de filtro.

Segundo Almeida (1988) e Reigosa et al. (1999), mudanças na atividade de certos aleloquímicos ocorrem porque estes sofrem degradação por microrganismos 


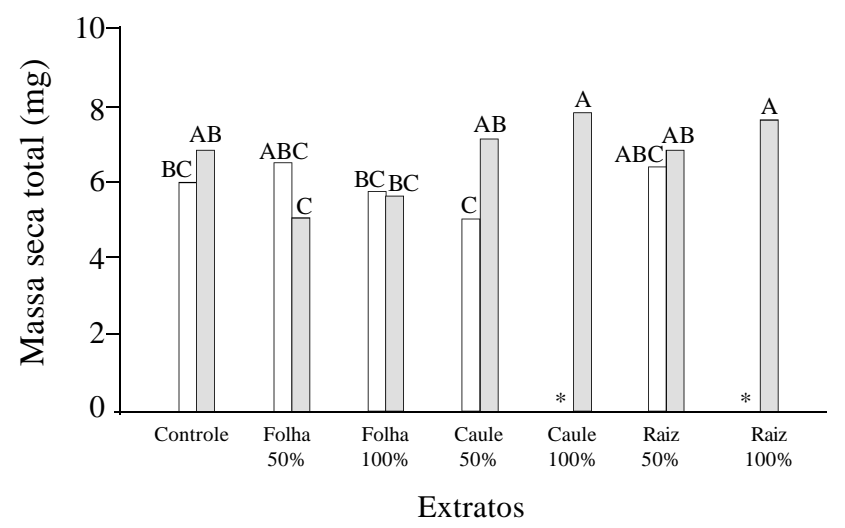

Figura 10. Valores médios de massa seca total de plântulas normais de rabanete (Raphanus sativus L.) crescidas em papel de filtro e fibra de coco, umedecidos com diferentes extratos (folha, caule e raiz) de Aristolochia esperanzae O. Kuntze, em duas concentrações (50 e $100 \%$, mais o controle - 0\%). Médias seguidas pelas mesmas letras não diferem entre si, pelo teste de Duncan a $5 \%$ de probabilidade. $*=$ todas as plântulas anormais; $\square=$ Papel filtro; $\square=$ Fibra de coco.

no solo. Neste ambiente, a força de adsorção das micelas pode exercer papel importante, seqüestrando os possíveis aleloquímicos (Inderjit \& Dakshini 1999 in Ferreira \& Aquila 2000). A textura e a aeração do solo também interferem na atividade dos compostos químicos (Pires \& Oliveira 2001).

No bioensaio de crescimento observou-se que alguns resultados, provenientes dos extratos em concentrações menores (50\%), apresentaram estímulo no crescimento de plântulas de alface e rabanete tanto para a altura das plântulas quanto para o comprimento da raiz. Segundo Rice (1984), alguns compostos químicos tem atividade alelopática inibitória em altas concentrações e, em menores, podem estimular o mesmo processo. Reigosa et al. (1999) explicou este fato afirmando que os aleloquímicos podem atuar em vários processos simultaneamente e ter uma resposta diferenciada para o mesmo ou para diferentes processos, dependendo da concentração deste composto.

Características físico-químicas - quanto às características físico-químicas obtidas para os extratos de A. esperanzae, pode-se notar que os valores de $\mathrm{pH}$ variaram entre 5,1 e 5,62 (Tab. 2), verificando baixa variação entre estes valores e indicando baixa acidez. Valores próximos foram obtidos por Aquila (2000), que encontrou variação de $\mathrm{pH}$ entre 5,1 e 6,4 para extratos de Ilex paraguariensis.

Os valores de potencial osmóticos obtidos para os extratos de A. esperanzae apresentaram variação entre -0,13 e -0,35 MPa obtidos, respectivamente, para os extratos de raiz e folha (Tab. 2).

Quando colocadas para germinar em soluções de PEG-6000, as sementes de alface e rabanete responderam diferentemente uma da outra: depois de três dias observou-se que todas as sementes de rabanete haviam germinado com os potenciais osmóticos variando de 0 até o de - $0,4 \mathrm{MPa}$. No entanto, todas as sementes de alface germinaram nos potenciais de 0 e -0,2 MPa; nas soluções de -0,3 e - $-0,4 \mathrm{MPa}$ germinaram respectivamente 33 e $20 \%$ das sementes. Este resultado manteve-se até o $7^{\circ}$ dia após a montagem do experimento.

O potencial osmótico obtido para o extrato da folha de $A$. esperanzae foi de $-0,35 \mathrm{MPa}$; este valor sugere possível interferência do potencial osmótico do extrato nos resultados de germinação das sementes de alface. No entanto, subfrações deste extrato purificadas através da eluição em acetato de etila na concentração de $4 \mathrm{mg} / \mathrm{mL}$ confirmaram a atividade alelopática.

Os potenciais osmóticos obtidos para os demais extratos provenientes dos outros órgãos (caule, raiz, flor e fruto) de $A$. esperanzae variaram de $-0,13$ a $-0,23 \mathrm{MPa}$, considerando que soluções com potenciais osmóticos próximos de -0,2 MPa não interfiram significativamente na germinação das sementes de alface e rabanete, pode-se inferir que a redução na velocidade e percentagem de germinação destas sementes (Fig. 1 e 2) tenham acontecido, principalmente, pela presença de substâncias com atividade alelopática nestes extratos.

Quanto aos valores de rendimento de material vegetal para os extratos de A. esperanzae, pode-se observar que o extrato de folha foi aquela que obteve maior rendimento $(28,5 \mathrm{mg} / \mathrm{mL})$, seguido dos de fruto e flor. Os extratos de raiz e caule obtiveram valores inferiores (Tab. 2). Aquila (2000), calculando o rendimento dos extratos de Ilex paraguariensis, obteve

Tabela 2. Características físico-químicas dos extratos de folha, caule, raiz, flor e fruto de Aristolochia esperanzae O. Kuntze medidos na concentração de $100 \%$.

\begin{tabular}{llcc}
\hline & \multicolumn{3}{c}{$\begin{array}{c}\text { Características físico-químicas dos extratos } \\
\text { de Aristolochia esperanzae }\end{array}$} \\
\cline { 2 - 4 } Extratos & $\mathrm{pH}$ & $\begin{array}{c}\text { Potencial osmótico } \\
(\mathrm{MPa})\end{array}$ & $\begin{array}{c}\text { Rendimento } \\
(\mathrm{mg} / \mathrm{mL})\end{array}$ \\
\hline Folha & 5,1 & $-0,35$ & 28,575 \\
Caule & 5,23 & $-0,19$ & 10,035 \\
Raiz & 5,62 & $-0,13$ & 12,195 \\
Flor & 5,27 & $-0,22$ & 19,615 \\
Fruto & 5,5 & $-0,23$ & 22,94 \\
\hline
\end{tabular}


valores de rendimento entre 98 e $192 \mathrm{mg} / \mathrm{mL}$, ou seja, superiores aos encontrados para $A$. esperanzae (Tab. 2).

Ao analisar a resposta das sementes e plântulas sob influência dos extratos dos diferentes órgãos de Aristolochia esperanzae observou-se que os extratos de folha foram inibitórios na germinação das sementes, porém os extratos de caule e raiz, em geral, inibiram o crescimento e causaram anormalidades nas plântulas.

Pode-se dizer que os extratos de A. esperanzae possuem atividade alelopática sobre sementes de alface e rabanete e que, possivelmente, esta espécie possa, através desta atividade, influenciar a sucessão de plantas nos campos cerrados, uma vez que esta é planta pioneira e se encontra amplamente distribuída em seu ambiente.

Segundo Reigosa et al. (1999) a sucessão pode ser afetada pela alelopatia, permitindo a permanência de espécies como pioneiras graças à liberação de aleloquímicos. Almeida (1988) e Pinã-Rodrigues \& Lopes (2001) enfatizaram esta relação em espécies de gramíneas forrageiras.

Diante da metodologia aplicada e dos resultados obtidos pode-se inferir possível atividade alelopática de A. esperanzae sobre as sementes estudadas e esta sugestão é confirmada pelas conclusões que se seguem.

Os extratos aquosos de folha foram os que provocaram maior inibição da germinação das sementes de alface e rabanete; todos os extratos e concentrações retardaram a germinação de sementes de alface e rabanete; os extratos de caule e raiz causaram anormalidade nas plântulas de alface e rabanete, e em alguns casos, na concentração de $100 \%$, também provocaram mortalidade; embora tenham proporcionado comportamento diferenciado, é possível a utilização dos dois substratos para avaliação do crescimento inicial de plântulas; o uso de papel de filtro umedecido com os diferentes extratos causou maior efeito inibitório no crescimento das plântulas, se comparado com a fibra de coco; entre os extratos de maior concentração (100\%), o de folha foi o que menos inibiu o crescimento das plântulas, e na maioria dos casos o de raiz foi o que mais inibiu; a concentração dos extratos foi a principal responsável pelo estímulo ou inibição causada no crescimento das plântulas de alface e rabanete.

\section{Agradecimentos}

Os autores agradecem ao CNPq pelo apoio no trabalho e pela bolsa de Mestrado concedida ao primeiro
Autor; aos Professores Dr. Carlos Alberto R. Diniz e Alberto Peret, pela orientação nas análises estatísticas; às empresas "HORTEC Sementes", pela doação das sementes; "AMAFIBRA/SOCOCO", pela doação da fibra de coco.

\section{Bibliografia}

Almeida, F.S. 1988. A alelopatia das plantas. IAPAR, Londrina.

Aquila, M.E.A. 2000. Efeito alelopático de Ilex paraguariensis A. St.-Hil. na germinação e crescimento inicial de Lactuca sativa L. Iheringia 53 (Sér. Bot): 51-66.

Astarita, L.V.; Ferreira, A.G.; Bergonci, J.I. 1996. Mimosa bimucronata: Allelopathy and osmotic stress. Allelopathy Journal 3(1): 43-50.

Bagchi, G.D.; Jain, D.C. \& Cimap, P.O. 1997. Arteether: a potent plant growth inhibitor from Artemisia annua. Phytochemistry 45(6): 1131-1133.

Baruah, N.C.; Sarma, J.C.; Sarma, S. \& Sharma, R.P. 1994. Seed germination and growth inhibitory cadinenes from Eupatorium adenophorum Spreng. Journal of Chemical Ecology 20(8): 1885-1892.

Benincasa, M.M.P. 1988. Análise de crescimento da plantas. FUNEP, Jaboticabal.

Brasil. 1992. Regras para análise de sementes. SNDA/ DNDV/CLAV, Ministério da Agricultura e Reforma Agrária, Brasília.

Capellari Jr., L. 1992. Espécies de Aristolochia (Aristolochiaceae) ocorrentes no Estado de São Paulo. Dissertação de Mestrado, Universidade Estadual de Campinas, Campinas.

Chou, C.H. 1986. The role of allelopathy in subtropical agroecosystems of Taiwan. Pp. 57-73. In: A.R. Putnan \& C.S. Tang. The science of allelopathy. John Wiley \& Sons, New York.

Chou, C.H.; Fu, C.Y.; Li, S.Y. \& Wang, Y.F. 1998. Allelopathic potential of Acacia confusa and related species in Taiwan. Journal of Chemical Ecology 24(12): 2131-2150.

Chou, C.H. 1999. Roles of allelopathy in plant biodiversity and sustainable agriculture. Critical Reviews in Plant Science 18(5): 609-636.

Delachiave, M.E.A.; Rodrigues, J.D. \& Ono, E.O. 1999. Efeitos alelopáticos de losna (Artemisia absinthium L.) na germinação de sementes de pepino, milho, feijão e tomate. Revista Brasileira de Sementes 21(2): 265-269.

Durigan, J.C. \& Almeida, F.L.S. 1993. Noções sobre a alelopatia. FUNEP, Jaboticabal.

Einhellig, F.A. 1986. Mechanisms and modes of action of allelochemicals. Pp. 171-188. In: A.R. Putnan \& C.S. Tang. The science of allelopathy. John Wiley \& Sons, New York.

Einhellig, F.A. 1996. Interactions involving allelopathy in cropping systems. Agronomy Journal 88: 886-893.

Ferreira, A.G. \& Aquila, M.E.A. 2000. Alelopatia: uma área emergente da ecofisiologia. Revista Brasileira de Fisiologia Vegetal 12(Edição especial): 175-204. 
Ferri, M.G. 1969. Plantas do Brasil - Espécies do cerrado. Editora Edgard Blucher Ltda e Editora da Universidade de São Paulo, São Paulo.

Fischer, N.H. 1991. Plant terpenoids as allelopathic agents. Pp. 375-398. In: J.B. Harbone \& F.A. Tomas-Barberan (eds.). Ecological chemistry and biochemistry of plant terpenoids. Oxford Science Publications, New York.

Friedman, J. 1995. Allelopathy, autotoxicity, and germination. Pp. 629-644. In: J. Kegel \& G. Galili (eds.). Seed development and germination. Marcel Dekker Inc., New York.

Harbone, J.B. 1991. Recent advances in the ecological chemistry of plant terpenoids. Pp. 399-426. In: J.B. Harbone \& F.A. Tomas-Barberan (eds.). Ecological chemistry and biochemistry of plant terpenoids. Oxford science publications, New York.

Harbone, J.B. 1997. Plant secondary metabolism. Pp. 132-155. In: M.J. Crawley (ed.). Plant Ecology. $2^{\text {nd }}$ ed. Blackwell Science Ltda.

Inderjit \& Dakshini, K.M.M. 1995. On laboratory bioassays in allelopathy. Botanical Review 61(1): 28-44.

Jacobi, U.S. \& Ferreira, A.G. 1991. Efeitos alelopáticos de Mimosa bimucronata (DC) OK. sobre espécies cultivadas. Pesquisa Agropecuária Brasileira 26(7): 935-943.

Juan Jiménez-Osornio, F.M.V.Z.; Kumamoto, J. \& Wasser, C. 1996. Allelopathic activity of Chenopodium ambrosioides L. Biochemical Systematics and Ecology 24(3): 195-205.

Kato-Noguchi, H. 2003. Assessment of allelopathic potential of shoot powder of lemon balm. Scientia Horticulturae 97: 419-423.

Khan, Z.R.; Hassanali, A.; Overholt, W.; Khamis, T.; Hooper, A.M.; Pickett, J.A.; Wadhams, L.J. \& Woodcock, C.M. 2002. Control of witchweed Striga hermonthica by intercropping with Desmodium spp., and the mechanism defined as allelopathic. Journal of Chemical Ecology 28(9): 1871-1885.

Kong, C; Hu, F. \& Xu, X. 2002. Allelopathic potential and chemical constituents of volatiles from Ageratum conyzoides under stress. Journal of Chemical Ecology 28(6): 1173-1182.

Labouriau, L.G. \& Valadares, M.B. 1976. On the germination of seeds of Calotropis procera. Anais da Academia Brasileira de Ciências 48: 263-284.

Labouriau, L.G. 1983. A germinação de sementes. OEA, Washington, DC.

Lopes, L.M.X.; Bolzani, V.S. \& Trevisan, L.M.V. 1987. lorodane diterpenes from Aristolochia species. Phytochemistry 26(10): 2781-2784.

Lopes, L.M.X. \& Bolzani, V.S. 1988. Lignans and diterpenes of three Aristolochia species. Phytochemistry 27(7): 2265-2268.

Lopes, L.M.X.; Bolzani, V.S. \& Trevisan, L.M.V. 1988. Lignans from Brazilian Aristilochiaceae. Revista Latinoamericana de Química. 19(3-4): 113-117.

Mazzafera, P. 2003. Efeito alelopático do extrato alcoólico do cravo-da-índia e eugenol. Revista Brasileira de Botânica 26(2): 231-238.
Medeiros, A.R.M. \& Lucchesi, A.A. 1993. Efeitos alelopáticos da ervilhaca (Vicia sativa L.) sobre a alface em testes de laboratório. Pesquisa Agropecuária Brasileira 28(1): 9-14.

Miró, C.P.; Ferreira, A.G. \& Aquila, M.E.A. 1998. Alelopatia de frutos de erva-mate (Ilex paraguariensis) no desenvolvimento do milho. Pesquisa Agropecuária Brasileira 33(8): 1261-1270.

Nishimura, H. \& Mizutani, J. 1995. Identification of allelochemicals in Eucalyptus citriodora and Polygonum sachalinense. Pp.74-85. In: Inderjit; K.M.M. Dakshini \& F.A. Einhellig (eds.). Allelopathy - Organisms, Processes and Applications. American Chemical Society, Washington, DC.

Piña-Rodrigues, F.C.M. \& Lopes, B.M. 2001. Potencial alelopático de Mimosa caesalpinaefolia Benth sobre sementes de Tabebuia alba (Cham.) Sandw. Floresta e Ambiente 8(1): 130-136.

Pires, N.M. \& Oliveira, V.R. 2001. Alelopatia. Pp.145-185. (Cap. 5) In: R.S. Oliveira Jr. \& J. Constantin. Plantas daninhas e seu manejo (coords.). Agropecuária, Guaíba.

Pires, N.M.; Prates, H.T.; Pereira Filho, I.A.; Oliveira Jr., R.S. \& Faria, T.C.L. 2001. Atividade alelopática da leucena sobre espécies da plantas daninhas. Scientia Agricola 58(1): 61-65.

Priestap, H.A.; Ruveda, E.A.; Mascaret, O.A. \& Deulofeu, V. 1971. Aristolochic acids from aristolochia-argentina gris and Aristolochia esperanzae O. Kuntze. Anales de la Asociación Química Argentina 59(3-4): 245.

Putnan, A.R. \& Tang, C.S. 1986. Pp. 1-19. In: A.R. Putnan \& C.S. Tang. The science of allelopathy. John Wiley \& Sons, New York.

Rawat, M.S.M.; Pant, G.; Prasad, D.; Joshi, R.K. \& Pande, C.B. 1998. Plant growth inhibitors (Proanthocyanidins) from Prunus armeniaca. Biochemical Systematics and Ecology 26(1998): 13-23.

Reigosa, M.J.; Sánchez-Moreiras, A. \& Gonzáles, L. 1999. Ecophysiological approach in allelopathy. Critical Reviews in Plant Science 18(5): 577-608.

Rice, E.L. 1984. Allelopathy. Academic Press, London.

Rizvi, S.J.H.; Tahir, M.; Rizvi, V.; Kohli, R.K. \& Ansari, A. 1999. Allelopathy interactions in agroflorestry systems. Critical Reviews in Plant Science 18(6): 773-796.

Rodrigues, L.R.A.; Rodrigues, T.J.D. \& Reis, R.A. 1992. Alelopatia em plantas forrageiras. FCAVJ-UNESP/ FUNEP, Jaboticabal.

Saxena, A.; Singh, D.V. \& Joshi, N.L. 1996. Autotoxic effects of pearl millet aqueous extracts on seed germination and seedling growth. Journal of Arid Environments 33: 255-260.

Seigler, D.S. Chemistry and mechanisms of allelopathy interactions. 1996. Agronomy Journal 88: 876-885.

Souza Filho, A.P.S.; Rodrigues, L.R.A. \& Rodrigues, T.J.D. 1999. Effects of aqueous extracts of leucaena on germination and germination and radicle elongation of tree forage grasses. Pp. 391-395. In: F.A. Macías; J.C.G. Galindo; J.M.G. Molinillo \& H.G. Cutler (eds.). Recent advances in allelopathy - A science of the future. Cádiz, Espanha, Servicio de Publicaciones, Universidad de Cádiz. 
Vaccarini, C.E.; Palacios, S.M.; Meragelman, K.M. \& Sosa, V.E. 1999. Phytogrowth-inhibitory activities of a clerodane from Viguiera tucumanensis. Phytochemistry 50: 227-230.

Vaccarini, C.E. \& Bonetto, G.M. 2000. Selective phytotoxic activity of withanolides from Iochroma australe to crop and weed species. Journal of Chemical Ecology 26(9): 2187-2196.

Viles, R.N. \& Reese, R.N. 1996. Allelopathic potential of Echinacea angustifolia D.C. Environmental and Experimental Botany 36(1): 39-43.

Villela, F.A.; Doni Filho, L.; Sequeira, E.L. 1991. Tabela de potencial osmótico em função da concentração de polietileno glicol 6.000 e da temperatura. Pesquisa Agropecuária Brasileira 26(11/12): 1957-1968.
Weston, L.A. 1996. Utilization of allelopathy for weed management in agroecosystems. Agronomy Journal 88: 860-866.

Wu, H.; Haig, T.; Pratley, J.; Lemerle, D. \& AN, M. 2000. Distribuition and exudation of allelochemicals in wheat Triticum aestivum. Journal of Chemical Ecology 26(9): 2141-2154.

Yamada, K.; Anai, T. \& Hasegawa, K. 1995. Lepidimoide, an allelopathic substance in the exudates from germinated seeds. Phytochemistry 39(5): 1031-1032.

Yokotani-Tomita, K.; Goto, N.; Kosemura, S.; Yamamura, S. \& Hasegawa, K. 1998. Growth-promoting allelopathic substance exuded from germinating Arabidopsis thaliana seeds. Phytochemistry 47(1): 1-2. 